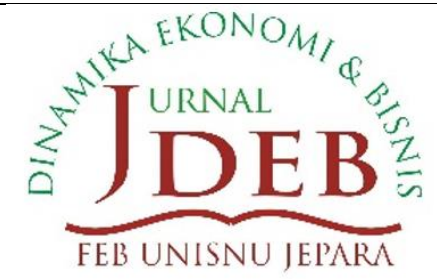

Jurnal Dinamika Ekonomi dan Bisnis, 16 (01) 2019, 1-104

https://ejournal.unisnu.ac.id/JDEB

Terakreditasi Sesuai Kutipan Keputusan Direktur Jenderal

Penguatan Riset dan Pengembangan, Kementerian Riset, Teknologi,

dan Pendidikan Tinggi Republik Indonesia Nomor: 21/E/KPT/2018

\title{
ANALISIS UNDERPRICING SAHAM DI BURSA EFEK INDONESIA PERIODE 2012-2017
}

\author{
Linda Defi Ariyani ${ }^{1)}$, Hadi Ismanto ${ }^{2)}$ \\ Universitas Islam Nahdlatul Ulama Jepara, Fakultas Ekonomi dan Bisnis ${ }^{1,2)}$ \\ Email: defiariyanilinda@yahoo.co.id ${ }^{1)}$, hadifeb@unisnu.ac.id ${ }^{2)}$
}

\section{Keywords: Abstract:}

Underpricing, IPO, ukuran perusahaan, reputasi auditor, financial leverage, EPS
The phenomenon of underpricing of IPOs of companies on the still occurs due to economic uncertainty and a large information asymmetry. As many as 31 companies offered their shares to the primary market and underpricing. This study aims to provide empirical evidence regarding the factors that determine the underpricing of IPO shares on the from 2012 to 2017, including company size, auditor reputation, financial leverage, and EPS. This research uses a quantitative approach using 84 companies. The results of multiple linear regression indicate that stock underpricing is influenced by company size and auditor reputation, whereas Financial leverage and EPS do not lead to underpricing of IPO shares. Investors can consider the company's size and auditor's reputation as a benchmark for valuing IPO shares. This study also provides evidence that underpricing of IPOs can illustrate investor behavior in valuing developing companies 


\section{Kata kunci: Abstrak:}

Underpricing, IPO, ukuran Fenomena underpricing IPO perusahaan di Bursa Efek perusahaan, reputasi auditor, Indonesia masih terjadi karena ketidakpastian ekonomi financial leverage, EPS. dan asimetri informasi yang besar. Tercatat sebanyak 31 perusahaan yang menawarkan sahamnya ke pasar perdana dengan harga lebih rendah dibanding ketika diperdagangkan di pasar sekunder. Penelitian ini bertujuan untuk memberikan bukti empiris mengenai faktor-faktor yang menentukan underpricing saham IPO di BEI dari tahun 2012 hingga tahun 2017, meliputi ukuran perusahaan, reputasi auditor, financial leverage, dan EPS. Penelitian ini menggunakan pendekatan kuantitatif menggunakan 84 perusahaan dengan teknik purposive sampling. Dengan menggunakan regresi linier berganda, menunjukkan bahwa underpricing saham dipengaruhi oleh ukuran perusahaan dan reputasi auditor. Untuk Financial leverage dan EPS tidak mengarah terjadinya underpricing saham IPO. Ukuran perusahaan yang lebih besar dan reputasi auditor yang baik mengarah pada tingkat underpricing yang lebih rendah. Investor dapat mempertimbangkan ukuran perusahaan dan reputasi auditor sebagai tolok ukur menilai saham IPO. Studi ini juga memberikan bukti bahwa underpricing IPO dapat menggambarkan perilaku investor dalam menilai perusahaan yang sedang berkembang. 


\section{PENDAHULUAN}

Untuk mencapai tujuan perusahaan diperlukan sumber daya modal dalam mengembangkan perusahaan (Kartika dan Putra, 2017). Perusahaan memiliki berbagai alternatif pilihan untuk mendapatkan sumber daya modal baik dari internal atau eksternal perusahaan. Alternatif pendanaan internal termasuk laba ditahan dan depresiasi. Sedangkan alternatif pendanaan eksternal berasal dari penyertaan modal pemegang saham (Altensy, 2015). Ketika proses go public, ekuitas perusahaan dijual dalam penawaran umum di pasar perdana (initial public offering/IPO) dengan harga cenderung rendah (Ljungqvist, 2007). Fenomena underpricing saham IPO di BEI masih tinggi karena ketidakpastian ekonomi dan asismetri informasi yang besar.

Meskipun secara teoritis, penerbitan prospektus bertujuan untuk mengurangi asimetri informasi tentang perusahaan pada saham IPO dan meminimalisir underpricing. Underpricing saham IPO dapat ditentukan oleh beberapa faktor antara lain ukuran perusahaan (Gu, 2003; Hastuti, 2015), reputasi auditor (Altensy, 2015; Razafindrambinina \& Kwan, 2013), Financial leverage (Indriani \& Marlia, 2014; Zhou \& Lao, 2012), dan laba per saham (EPS) (Chen, Hung, \& Wu, 2002; Misnen, 2003). Untuk itu, penelitian ini bertujuan untuk menguji dan menganalisis korelasi antara faktor-faktor penentu underpricing saham IPO di Bursa Efek Indonesia.

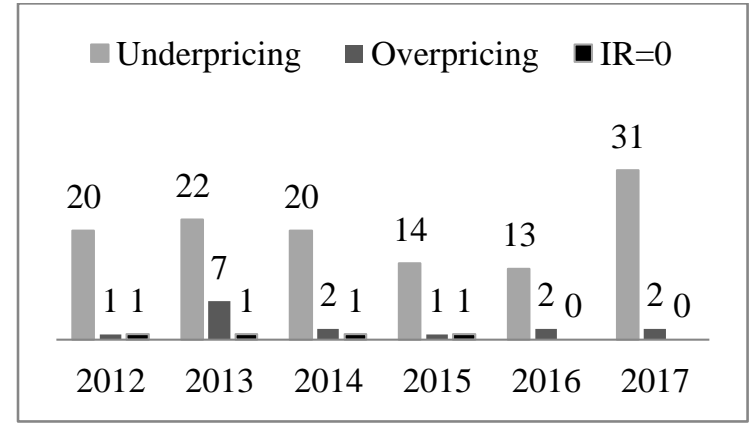

Sumber: IDX, 2019

Gambar 1. Fenomena Underpricing di BEI Tahun 2012 - 2017

Di tahun 2017 tercatat sebanyak 31 perusahaan yang menawarkan sahamnya ke pasar perdana dengan harga lebih rendah dibanding ketika diperdagangkan di pasar sekunder. Sementara hanya 2 perusahaan yang overpricing seperti dalam Gambar 1. Underpricing terjadi ketika ada perbedaan antara harga di mana saham IPO dijual kepada investor (harga penawaran) dan harga di mana saham selanjutnya diperdagangkan di pasar sekunder (Ljungqvist, 2007). Meski begitu, Chen et al. (2002) menyebutkan bahwa penawaran umum perdana (IPO) sengaja dibuat terlalu murah dan underpricing yang disengaja tidak bertanggung jawab atas pengembalian awal IPO.

\section{TINJAUAN PUSTAKA}

\section{Initial Public Offering (IPO)}

Initial Public Offering (IPO) atau penawaran umum perdana adalah kegiatan penjualan sekuritas kepada masyarakat baik perorangan maupun lembaga di pasar perdana (bursa efek) sebelum sekuritas diperdagangkan di pasar sekunder (Hastuti, 2015). Perusahaan yang melakukan penawaran saham perdana telah mengubah status perusahaannya menjadi perusahaan public, yang mana sebelumnya saham perusahaan dimiliki oleh pemilik dan 
manajer-manajernya. Menurut Ritter \& Welch (2002), ada dua alasan utama perusahaan melakukan IPO, yaitu alasan financial dan non finansial. Alasan finansial adalah keinginan untuk meningkatkan ekuitas perusahaan dan menciptakan pasar publik di mana para pendiri dan pemegang saham lainnya dapat mengubah sebagian kekayaan mereka menjadi uang tunai di masa mendatang. Sedangkan alasan nonfinancial, seperti peningkatan publisitas.

\section{Underpricing IPO}

Underpricing IPO terjadi ketika ekuitas perusahaan dijual di pasar perdana dengan harga lebih rendah daripada ketika diperdagangkan di pasar sekunder (Agulina, 2014; Ljungqvist, 2007). Yolana dan Martani (2005) mendefinisikan underpricing sebagai selisih positif harga saham pada saat IPO, yaitu harga saham di pasar sekunder lebih tinggi dari harga penawaran awalnya. Selisih ini disebut dengan istilah initial return (IR).

Fenomena underpricing disebabkan karena adanya ketidakpastian harga (mispriced) di pasar perdana akibat ketidakseimbangan informasi antara pihak underwriter dengan pihak emiten (Loughran \& Ritter, 2004). Terdapat dua sisi pendapat yang saling bertentangan yakni emiten sebagai pihak yang membutuhkan dana, pasti menginginkan harga saham perdana yang tinggi, di sisi lain underwriter sebagai penjamin menginginkan harga yang rendah demi mengurangi risiko yang ditanggungnya. Besarnya underpricing saham dapat diketahui melalui perhitungan initial return (Andreyas, 2016). Rumus IR yaitu:

$$
\mathrm{IR}=\frac{(\mathrm{Pt} 1-\mathrm{Pt} 0)}{\mathrm{Pt} 0} \times 100 \%
$$

\section{Teori Asimetri Informasi}

Fenomena underpricing terjadi disebabkan oleh adanya asimetri informasi antara emiten dan penjamin emisi, maupun antara investor (Handayani \& Shaferi, 2011). Dalam kaitannya dengan asimetri informasi terdapat dua model yang dapat menjelaskan adanya asimetri informasi. Pada model Baron (1982) menjelaskan perbedaan informasi terjadi antara emiten dengan penjamin emisi (underwriter). Underwriter dianggap memiliki informasi yang lebih banyak mengenai kondisi pasar dari pada emiten. Informasi tersebut dimanfaatkan oleh underwriter untuk memperkecil risiko beli karena saham yang tidak laku dijual dengan kesepakatan harga yang lebih rendah.

Model kedua adalah Rock (1986) yang melihat asimetri informasi dari sisi investor, yaitu informed investor dan uninformed investor. Investor yang memiliki informasi akan membeli saham perusahaan IPO jika mereka yakin bahwa harga saham setelah IPO akan lebih tinggi, sedangkan uninformed investor akan membeli saham perusahaan IPO secara sembarangan.

\section{Ukuran Perusahaan}

Kartika dan Putra (2017) mengatakan bahwa ukuran perusahaan merupakan sinyal perusahaan memiliki kemampuan melakukan kegiatan usaha dengan baik. Ukuran perusahaan dapat diketahui dari logaritma total aset perusahaan (Hastuti, 2015). Aset menciptakan nilai dan karenanya memungkinkan semua pihak untuk mengevaluasi prospek masa depan 
perusahaan dengan lebih pasti (Daugherty \& Jithendranathan, 2012). Kepastian masa depan mampu mengurangi asimetri informasi penawaran perdana suatu saham (Muharam dan Firmanah, 2015), sehingga underpricing terminimalisir (Handayani \& Shaferi, 2011). Rumus ukuran perusahaan adalah Hastuti (2015):

$$
\text { Size }=\text { Ln (Total Assets) }
$$

H1: Ukuran perusahaan berpengaruh terhadap underpricing

\section{Reputasi Auditor}

Sebelum laporan keuangan dipublikasikan terlebih dahulu telah melewati proses pemeriksaan (auditing) oleh tim auditor yang tersertifikasi untuk tersampainya informasi yang akurat dan relevan kepada publik. Laporan keuangan auditan sangat dibutuhkan untuk pengambilan keputusan baik bagi pihak internal perusahaan maupun eksternal (investor) dan memberikan tingkat kepercayaan yang lebih tinggi (Yasa, 2008). Reputasi auditor menjadi sangat penting untuk menarik minat investor. Razafindrambinina \& Kwan (2013) berargumen dalam hasil penelitiannya bahwa pemilik perusahaan IPO dapat memilih auditor berdasarkan reputasi yang kuat daripada kualitas auditnya. Perusahaan yang menggunakan auditor bereputasi big four menunjukkan underpricing yang lebih rendah (Kristiantari, 2013; Pahlevi, 2014; Razafindrambinina \& Kwan, 2013).

H2: Reputasi auditor berpengaruh terhadap underpricing

\section{Financial Leverage}

Financial leverage merupakan rasio keuangan yang menunjukkan tingkat risiko perusahaan yang dikaitkan dengan ketidakpastian ex-ante, akibatnya struktur modal tidak dapat digunakan sebagai sinyal yang kredibel dari prospek masa depan perusahaan (Su, 2004). Leverage menunjukkan proporsi utang perusahaan terhadap modal yang dimiliki (Indriani \& Marlia, 2014). Nilai leverage yang tinggi mencerminkan risiko keuangan yang lebih tinggi dari perusahaan. Besarnya risiko perusahaan dalam hal memenuhi kewajibannya berdampak pada penetapan harga saham pada saat penawaran perdana dan memungkinkan potensi terjadinya underpricing (Gunawan \& Jordin, 2015; Pahlevi, 2014). Rumus Financial leverage yaitu Pahlevi (2014):

$$
\mathrm{DER}=\frac{\text { Total Debt }}{\text { Equity }}
$$

H3: Financial leverage berpengaruh terhadap underpricing

\section{Earning per Share}

Earning per share (EPS) adalah pendapatan perusahaan selama periode tertentu yang dapat dihitung dengan membandingkan antara earning after tax dengan jumlah saham perusahaan yang beredar (Muharam \& Firmanah, 2015). Dalam hubungannya dengan perusahaan yang akan melakukan go public, informasi terkait kemampuan perusahaan memperoleh pendapatan dan menghasilkan arus kas di masa datang akan membantu investor dalam menilai perusahaan (Handayani \& Shaferi, 2011). Nilai EPS yang lebih tinggi memungkinkan terjadinya peningkatan jumlah dividen yang diterima oleh pemegang saham. Hal ini akan menarik perhatian investor untuk membeli saham perusahaan pada penawaran perdana sehingga menyebabkan harga dan return saham perdana lebih 
tinggi (Andreyas, 2016). Rumus EPS adalah Muharam dan Firmanah (2015):

$$
\text { EPS }=\frac{\text { Net Income After Tax }}{\text { Jumlah Lembar Saham }}
$$

H4: Earning per share berpengaruh terhadap underpricing

\section{METODE}

Variabel dependen penelitian adalah underpricing saham IPO (UNDER), sedangkan variabel independen meliputi ukuran perusahaan (SIZE), reputasi auditor (AUDIT), Financial leverage (LVRG), dan earning per share (EPS). Variabel UNDER diukur mengacu rumus yang digunakan oleh Andreyas (2016). Untuk variabel SIZE menggunakan Hastuti (2015), variabel LVRG dari Pahlevi (2014), dan variabel EPS dari Muharam dan Firmanah (2015). Pengukuran variabel AUDIT merupakan variabel dummy yaitu skor 1 untuk perusahaan yang menggunakan auditor big four dan skor 0 untuk perusahaan yang tidak menggunakan auditor big four (Pahlevi, 2014).

Data sekunder digunakan dengan metode observasi dan dokumentasi, yaitu mengambil informasi yang dibutuhkan dari website BEI dan laporan keuangan perusahaan yang melakukan IPO dari tahun 2012 hingga 2017. Jumlah sampel penelitian sebanyak 84 perusahaan IPO dengan kriteria purposive sampling dalam Tabel 1. Data tersebut dianalisis menggunakan SPSS melalui uji normalitas dan asumsi klasik untuk memperoleh model regresi yang layak (Ghozali, 2013) Berikut model regresi berganda penelitian. UNDER $=\mathrm{a}+\mathrm{b} 1$ SIZE + b2AUDIT $+\mathrm{b} 3 \mathrm{LVRG}+\mathrm{b} 4 \mathrm{EPS}+\mathrm{e}$

Tabel 1. Kriteria Pengambilan Sampel

\begin{tabular}{ll}
\hline \multicolumn{1}{c}{ Kriteria Pengambilan Sampel } & Jumlah \\
\hline Perusahaan IPO tahun 2012-2017 & 139 \\
Perusahaan overpricing & $(15)$ \\
Perusahaan IR =0 & $(4)$ \\
$\begin{array}{l}\text { Perusahaan yang datanya tidak } \\
\text { lengkap }\end{array}$ & $(3)$ \\
$\begin{array}{l}\text { Perusahaan yang laporan keuangannya } \\
\text { tidak menggunakan rupiah }\end{array}$ & $(12)$ \\
$\begin{array}{l}\text { Perusahaan yang mengalami } \\
\text { volatilitas }\end{array}$ & $(16)$ \\
$\begin{array}{l}\text { Data Outlier } \\
\text { Perusahaan yang terpilih sebagai } \\
\text { sampel }\end{array}$ & $(5)$ \\
\hline
\end{tabular}

\section{Hasil}

\section{Deskripsi Variabel}

Berdasarkan hasil statistik deskriptif pada Tabel 2, rata-rata underpricing selama tahun 2012 hingga 2017 sebesar 0,307 dengan nilai minimum 0,003 dan nilai maksimum 0,780. Perusahaan yang melakukan IPO pada periode penelitian menunjukkan rata-rata ukuran aset sebesar 27,565 dengan nilai minimum 23,3935 dan nilai maksimum 29,6595, sedangkan ratarata rasio DER perusahaan sebelum IPO sebesar 2,300 dengan nilai minimum 0,031 dan nilai maksimum 14,126. Perusahaan IPO juga rata-rata menggunakan auditor big four sebanyak 0,157 atau $15,7 \%$ dan sisanya sebanyak $84,3 \%$ tidak menggunakan auditor big four.

Tabel 1. Statistik Deskriptif 


\begin{tabular}{lcrrrr}
\hline & N & Minimum & Maximum & Mean & $\begin{array}{c}\text { Std. } \\
\text { Deviation }\end{array}$ \\
\hline UNDER & 89 &, 003 &, 780 &, 30698 &, 26342 \\
SIZE & 89 & 23,39351 & 29,65954 & 27,56534 & 1,17244 \\
AUDIT & 89 & 0,00000 & 1,00000 & 0,15730 & 0,36615 \\
LVRG & 89 &, 03069 & 14,12632 & 2,30020 & 2,37986 \\
EPS & 89 & $-60,5800$ & 68957,3100 & 1434,5328 & 8171,7087 \\
\hline Sumber: Data yang diolah, 2019 & & &
\end{tabular}

\section{Asumsi Klasik}

\section{Uji Normalitas}

Pendekatan yang digunakan adalah Kolmogorov-Smirnov dengan signifikan 5\%. Pada pengujian awal menunjukkan nilai Asymp. Sig kurang dari 0,05 atau berdistribusi tidak normal. Setelah melalui proses outlier data menunjukkan bahwa sebaran data telah normal sebagaimana dalam Tabel 3.

Tabel 3. Hasil Uji Normalitas dan Asumsi Klasik

\begin{tabular}{llrl}
\hline Model & Tolerance & VIF \\
\hline 1 C & & \\
& SIZE &, 821 & 1,217 \\
& AUDIT &, 903 & 1,107 \\
& LVRG &, 809 & 1,236 \\
& EPS &, 940 & 1,064
\end{tabular}

a. Dependent Variable: UNDER

\begin{tabular}{ll}
\hline Asymp. Sig. (2-tailed) &, $168^{\mathrm{c}}$ \\
\hline Durbin-Watson & 2,107
\end{tabular}

Sumber: Data yang diolah, 2019

\section{Uji Multikolinieritas}

Untuk mendeteksi adanya gejala multikolinieritas, analisis VIF dan tolerance diperlukan. Diketahui dalam Tabel 3, bahwa seluruh variabel penelitian tidak menunjukkan gejala multikolinieritas dengan nilai VIF di bawah nilai 10 dan tolerance di atas angka 0,1 .

\section{Uji Heteroskedastisitas}

Gambar 2 menunjukkan hasil uji scatterplot graphic dimana titik-titik tersebar dengan baik pada bagian atas dan bagian bawah nilai 0. Dengan demikian, model penelitian ini homoskedastisitas yaitu adanya kesamaan variance dari residual pengamatan satu ke lainnya.

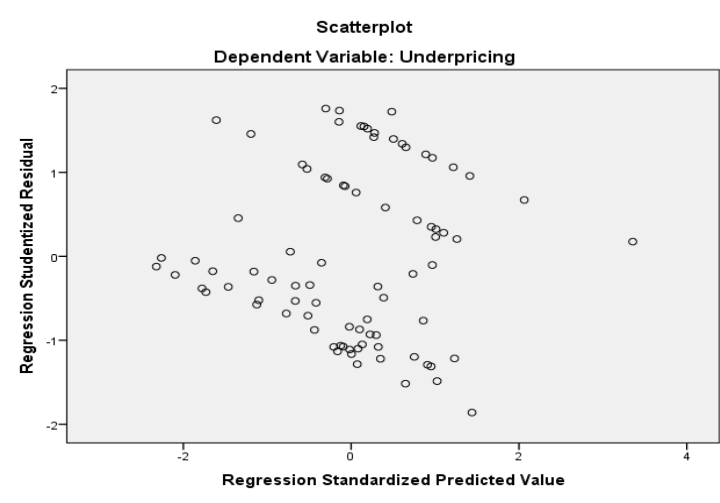

Gambar 2. Hasil Scatter-plot

Uji Autokorelasi

Berdasarkan uji Durbin-Watson yang terlihat dalam Tabel 3 menghasilkan nilai DW 2,107. Nilai tersebut berada diantara nilai dU dan 4-dU, sehingga model tidak terjadi autokorelasi.

\section{Analisis Regresi Linier Berganda}

Uji normalitas dan asumsi klasik terpenuhi dengan baik, maka model regresi dapat diterima untuk dianalisis lebih lanjut. 
Berdasarkan hasil statistic sebagaimana tampak pada Tabel 4, dapat ditentukan persamaan regresi berganda adalah sebagai berikut.

$$
\begin{gathered}
\text { UNDER }=2,261-0,070 \text { SIZE }- \\
\text { 0,183AUDIT + 0,006LVRG } \\
+0,00001548 \text { EPS + e }
\end{gathered}
$$

Ketika semua faktor dalam penelitian adalah konstan, maka angka underpricing saham IPO sebesar 2,261. Pada saat ukuran perusahaan dan reputasi auditor meningkat 1 satuan sedangkan variabel lainnya adalah konstan, maka underpricing menurun sebanyak 0,070 satuan dan 0,183 satuan. Akan tetapi, pada saat nilai Financial leverage dan EPS meningkat 1 satuan dan faktor lainnya adalah konstan, maka underpricing juga meningkat sebanyak

\begin{tabular}{|c|c|c|c|c|c|c|}
\hline \multirow{2}{*}{\multicolumn{2}{|c|}{ Model }} & \multicolumn{2}{|c|}{$\begin{array}{c}\text { Unstandardized } \\
\text { Coefficients }\end{array}$} & \multirow{2}{*}{$\begin{array}{c}\begin{array}{c}\text { Standardized } \\
\text { Coefficients }\end{array} \\
\text { Beta }\end{array}$} & \multirow{2}{*}{$\mathbf{t}$} & \multirow{2}{*}{ Sig. } \\
\hline & & B & $\begin{array}{c}\text { Std. } \\
\text { Error }\end{array}$ & & & \\
\hline \multirow[t]{5}{*}{1} & $\mathrm{C}$ & 2,261 &, 737 & & 3,067 & ,003 \\
\hline & SIZE &,- 070 & ,027 &,- 291 & $-2,603$ & 011 \\
\hline & AUDIT &,- 183 & ,075 &,- 258 & $-2,421$ & 018 \\
\hline & LVRG & ,006 & ,016 & ,046 & ,412 & ,682 \\
\hline & EPS & $1,548 \mathrm{E}-05$ & ,000 & ,095 & 909 & ,366 \\
\hline \multicolumn{4}{|c|}{ a. Dependent Variable: UNDER } & & & \\
\hline \multicolumn{4}{|c|}{ Uji $F$} & & 4,572 &, $002^{b}$ \\
\hline \multicolumn{4}{|c|}{ Adjusted R Square } & & ,147 & \\
\hline
\end{tabular}
0,006 satuan dan 0,00001548 satuan.

\section{Tabel 4. Hasil Pengujian Hipotesis}

\section{Koefisien Determinasi}

Berdasarkan Tabel 4 menunjukkan bahwa tingkat underpricing perusahaan IPO tahun 2012 hingga 2017, sebesar 14,7\% dapat dijelaskan oleh variabel SIZE, AUDIT, LVRG, dan EPS. sedangkan sisanya 85,3\% dipengaruhi oleh faktor lainnya.

\section{Pengujian Hipotesis}

\section{Pengaruh Ukuran Perusahaan dengan}

\section{Underpricing}

Dalam Tabel 4 dapat dilihat $\mathrm{t}$ hitung ukuran perusahaan sebesar -2,603 dengan nilai signifikansi 0,011. Dengan demikian, ukuran perusahaan berpengaruh negatif dan signifikan terhadap underpricing dengan. Maka dapat disimpulkan bahwa semakin besar ukuran perusahaan tingkat underpricing perusahaan juga akan semakin rendah.

\section{Pengaruh Reputasi Auditor dengan Underpricing}

Berdasarkan Tabel 4 menunjukkan t hitung reputasi auditor sebesar -2,421 dengan nilai signifikansi 0,018. Ini berarti reputasi auditor berpengaruh negatif dan signifikan terhadap underpricing. Maka dapat diambil kesimpulan bahwa semakin tinggi reputasi auditor maka tingkat underpricing akan semakin rendah.

\section{Pengaruh Financial leverage dengan Underpricing}

Dalam Tabel 4 dapat dilihat nilai t hitung Financial leverage sebesar 0,412 dengan nilai signifikansi 0,025 . Hasil tersebut dapat diartikan bahwa Financial leverage tidak berpengaruh signifikan terhadap underpricing. Tidak berpengaruhnya Financial leverage terhadap underpricing 
ini karena rasio-rasio hutang relatif lebih mencerminkan risiko perusahaan.

\section{Pengaruh Earning per Share dengan Underpricing}

Berdasarkan Tabel 4 menunjukkan t hitung EPS sebesar 0,909 dengan nilai signifikansi 0,366. Ini berarti bahwa EPS tidak berpengaruh signifikan terhadap tingkat underpricing saham IPO. Rasio ini tidak dapat memberikan ekspektasi untuk memperoleh return terhadap investasi yang dilakukan.

\section{Uji Statistik-F}

Jika secara parsial menunjukkan korelasi dari variabel ukuran perusahaan dan reputasi auditor, maka pengaruh secara simultan tampak pada Tabel 4. Di mana nilai statistik-F sebesar 4,572 dengan signifikansi 0,002, artinya secara simultan ukuran perusahaan, reputasi auditor, financial leverage, dan EPS berpengaruh terhadap tingkat underpricing saham IPO.

\section{PEMBAHASAN}

\section{Hubungan Ukuran Perusahaan dengan Underpricing}

Berdasarkan pengujian statistik menunjukkan ukuran perusahaan berpengaruh negatif dan signifikan terhadap underpricing saham IPO. Berpengaruhnya ukuran perusahaan terhadap tingkat underpricing sejalan dengan teori asimetri informasi, yang pada umumnya perusahaan besar lebih dikenal oleh masyarakat daripada perusahaan kecil karena ketersediaan informasi mengenai perusahaan mudah diakses oleh investor. Ketersediaan informasi perusahaan secara lengkap akan mengurangi asimetri informasi dalam penawaran saham perdana, yang pada akhirnya underpricing terminimalisir. Penelitian ini sejalan dengan hasil dari Maulidya \& Lautania (2016), Kristiantari (2013), dan Gunawan \& Jordin (2015).

\section{Hubungan Reputasi Auditor dengan Underpricing}

Berdasarkan pengujian statistik menunjukkan reputasi auditor berpengaruh negatif dan signifikan terhadap underpricing saham IPO. Perusahaan yang menggunakan auditor bereputasi tinggi dapat membuat publik merasa yakin atas kebenaran laporan keuangan perusahaan, sehingga informasi yang dibutuhkan publik untuk menilai perusahaan dinilai lebih dipercaya. Selain itu juga dapat mengurangi tindakan kecurangan yang mungkin dilakukan oleh emiten pada saat IPO terhadap laporan keuangannya. Sehingga risiko dan ketidakpastian atas investasi dapat diminimalisair sehingga tingkat underpricing juga akan rendah. Hasil ini sejalan dengan penelitian Kristiantari (2013), Pahlevi (2014), dan Razafindrambinina \& Kwan (2013).

\section{Hubungan Financial leverage dengan Underpricing}

Berdasarkan pengujian statistik menunjukkan bahwa financial leverage menyebabkan kenaikan ataupun penurunan underpricing. Tidak berpengaruhnya leverage terhadap underpricing ini karena rasio hutang relatif lebih mencerminkan risiko perusahaan, perusahaan yang memiliki risiko tinggi cenderung dihindari oleh calon investor karena perusahaan dengan DER yang tinggi mencerminkan besarnya ketidakpastian perusahaan ke depan. Penelitian ini bertolak belakang dengan hasil penelitian Indriani \& Marlia (2014) dan Zhou \& Lao (2012). 


\section{Hubungan Earning per Share dengan Underpricing}

Berdasarkan pengujian statistik menunjukkan bahwa EPS tidak menyebabkan kenaikan ataupun penurunan underpricing. Apabila EPS semakin tinggi maka harapan untuk memperoleh keuntungan akan semakin besar, sehingga harga perdana yang diberlakukan oleh emiten akan mengalami peningkatan. Namun, rasio EPS bukan merupakan bahan pertimbangan dalam rangka menetapkan harga penawaran saham perdana karena rasio EPS yang dimiliki emiten sebelum melakukan IPO akan mengalami perubahan setelah emiten melakukan IPO karena adanya perkembangan laba perusahaan yang dipengaruhi oleh kebijakan pajak dan kondisi ekonomi. Hasil penelitian ini bertolak belakang dengan penelitian Chen et al. (2002) dan Misnen (2003).

\section{SIMPULAN DAN SARAN}

Berdasarkan hasil pengujian terhadap hipotesis melalui analisis regresi linier berganda, memperoleh beberapa simpulan penting. Pertama, hanya variabel ukuran perusahaan dan reputasi auditor yang berpengaruh terhadap underpricing saham IPO, sedangkan dua faktor lainnya tidak signifikan. Kedua, korelasi yang ditunjukkan ukuran perusahaan dan reputasi auditor terhadap tingkat underpricing adalah negatif. Ketiga, keempat faktor (ukuran perusahaan, reputasi auditor, financial leverage, dan EPS) secara bersama-sama menentukan tingkat underpricing saham IPO.

Hasil penelitian ini setidaknya dapat menjadi bahan evaluasi investor sebelum yakin bertransaksi di pasar perdana. Investor dapat memperhatikan informasi yang termuat dalam prospektus terutama mengenai ukuran perusahaan dan reputasi auditor yang dipakai perusahaan. Sementara perusahaan dapat memperhatikan rasio asetnya dan reputasi auditor yang digunakan sebelum menawarkan sahamnya untuk pertama kalinya.

\section{DAFTAR PUSTAKA}

Agulina, M. (2014). Pengaruh Ukuran Perusahaan dan Good Corporate Governance Terhadap Underpricing Saham Pada Saat Initial Public Offering pada Perusahaan NonKeuangan yang Terdaftar di BEI Periode 2009-2012. JOM Fekon, 1(2), 1-20.

Altensy, M. (2015). Pengaruh Informasi Keuangan, Non Keuangan dan Ekonomi Makro terhadap Underpricing pada Perusahaan yang Melakukan Initial Public Offering (IPO) Periode 2011-2013 di Bursa Efek Indonesia. Jom Fekon, 2(2), 115.

Andreyas, L. (2016). Pengaruh Faktor Keuangan dan Good Corporate Governance Terhadap Underpricing Pada Perusahaan IPO.

Baron, D. P. (1982). A Model Of The Demand for Investment Banking Advising and Distribution Services for New Issues. The Journal of Finance, 37(4), 955-976.

Chen, A., Hung, C. C., \& Wu, C.-S. (2002). The Underpricing and Excess Returns of Initial Public Offerings in Taiwan Based on Noisy Trading: A Stochastic Frontier Model. Review of Quantitative Finance and Accounting, 18(2), 139-159.

Daugherty, M. S., \& Jithendranathan, T. (2012). Underpricing of IPOs of U.S. Family ControlledBusinesses. International Research Journal of 
Finance and Economics, (90), 193206.

Ghozali, I. (2013). Aplikasi Analisis Multivariate dengan Program SPSS 21 (7th ed.). Semarang: Badan Penerbit Universitas Diponegoro.

Gu, A. Y. (2003). State Ownership, Firm Size, and IPO Performance: Evidence from Chinese "A" Share Issues. American Business Review, 21(2), 101.

Gunawan, M., \& Jordin, V. (2015). Faktorfaktor yang Mempengaruhi Tingkat Underpricing Saham pada Perusahaan yang melakukan Initial Public Offering yang Terdaftar di Bursa Efek Indonesia. Jurnal Ekonomi, XX(02), 174-192.

Handayani, S. R., \& Shaferi, I. (2011). Analisis Faktor-faktor yang Mempengaruhi Underpricing pada Penawaran Umum Perdana (Studi Kasus pada Perusahaan Keuangan yang Go Publik di Bursa Efek Jakarta Tahun 2000-2006). Performance, 14(2), 103-118.

Hastuti, R. T. (2015). Analisis FaktorFaktor yang Mempengaruhi Fenomena Underpricing Saham Pada Saat IPO di Bursa Efek Indonesia Pada Periode 2008-2013. Jurnal Ekonomi, XX(01), 1-19.

Indriani, S., \& Marlia, S. (2014). The Evidence of IPO Underpricing in Indonesia 2009 - 2013. Review of Integrative Business \& Economics Research, 4(1), 299-316.

Kartika, G. A. S., \& Putra, I. M. P. D. (2017). Faktor-faktor Underpricing Initial Public Offering di Bursa Efek Indonesia. E-Jurnal Akuntansi Universitas Udayana, 19(3), 22052233.

Kristiantari, I. D. A. (2013). Analisis Faktor-faktor yangMempengaruhi Underpricing Saham Perdana di
Bursa Efek Indonesia. Jurnal Ilmiah Akuntansi Dan Humanika, 2(2), 785811.

Ljungqvist, A. (2007). IPO underpricing. In Handbook of Empirical Corporate Finance (pp. 375-422). Elsevier.

Loughran, T., \& Ritter, J. R. (2004). Why Has IPO Underpricing Changed Over Time? Financial Management, 33(3), 5-37.

Maulidya, P. S., \& Lautania, M. F. (2016). Pengaruh Asset Turnover, Current Ratio, Debt to Equity Ratio, dan Ukuran Perusahaan di Pasar Penawaran Saham Perdana yang Terdaftar di Bursa Efek Indonesia Tahun 2010-2014. Jurnal Ilmiah Mahasiswa Ekonomi Akuntansi (JIMEKA), 1(1), 171-182.

Misnen, A. (2003). Effect Of Financial Variables on Initial Return and 15 Days Return After The IPO in Jakarta Stock Exchange. Accounting National Symposium, 16-17.

Muharam, H., \& Firmanah, D. U. (2015). Analisis Pengaruh Informasi Non Keuangan, Informasi Keuangan, dan Ownership Terhadap Underpricing pada Perusahaan Non Keuangan yang Melakukan Initial Public Offering ( IPO ) di BEI Periode 2008-2014. Diponegoro Journal Of Manajement, 4(4), 1-12.

Pahlevi, R. W. (2014). Analisis Faktorfaktor yang Mempengaruhi Underpricing Saham pada Penawaran Saham Perdana di Bursa Efek Indonesia. Jurnal Siasat Bisnis, 18(2), 219-232.

Razafindrambinina, D., \& Kwan, T. (2013). The Influence of Underwriter and Auditor Reputations on IPO Under-pricing. European Journal of Business and Management, 5(2), 199-212. 
Ritter, J., \& Welch, I. (2002). A Review of IPO Activity, Pricing, and Allocations. The Journal of Finance, 57(4), 1795-1828.

Rock, K. (1986). Why New Issues are Underpriced. Journal of Financial Economics, 1(2), 187-212.

$\mathrm{Su}$ D. (2004). Leverage, Insider Ownership, and The Underpricing Of IPOs in China. Journal of International Financial Markets, Institutions and Money, 14(1), 3754.

Yasa, G. W. (2008). Penyebab Underpricing pada Penawaran Saham Perdana di Bursa Efek Jakarta. Jurnal Akuntansi Dan Bisnis, 3(2), 1-29.

Yolana, C., \& Martani, D. (2005). Variabel-variabel Mempengaruhi yang Underpricing pada Penawaran Saham Perdana di BEJ Tahun 1994-2001. Simposium Nasional Akuntansi VIII, 538-551/

Zhou, J., \& Lao, L.-J. (2012). Analysis of Influencing Factors of IPO Underpricing in ChiNext. Physics Procedia, 33, 846 - 851. 